mal has no other motions than those which are given it by the agitation of the liquid. During this period, small buds are distinguished, arranged in regular rows around the oral pole. Towards the twentieth day spiniform processes are developed on the top of these buds, of a great length in comparison to the bulk of the animal. The calcareous matter already enters so largely into their composition, that the least shock is sufficient to break them without making them bend.

I have followed the progress of the animal up to the moment when it is detached from its pedicle, doubtless to live under the form which it retains during the rest of its existence. However incomplete may be my observations, I think that they may give a general idea of the development of the Echinus, and allow us to draw from them the following deductions :-From the moment when the embryo has a form of its own, all the parts of its body are arranged almost symmetrically around the bucco-anal axis, and, consequently, it bears in the highest degree all the characters of the type of the zoological class in which it is arranged, that is to say, of the radiate type.

It is around the bucco-anal axis that the activity of the genesic process is manifested from its origin, and is maintained greater during the whole course of the development; and it is principally from the two extremities of this axis that it radiates, and extends gradually to the other parts of the tegumentary envelope.

Search as much as we may, in the arrangement of the different parts of the Echinus esculentus, for a tendency to bilateral development similar to that pointed out by M. Sars in an Asteria, not the least trace will be found, even during the shortest duration of one of the phases of the genesic phænomena. In the larva of the Echinus, when the body elongates as well as when it contracts, to return to nearly its primitive configuration, these changes take place in the direction of the bucco-anal axis, so that the radiate form is not at all affected by it. In short, as soon as we can discover the first organic lineaments of this being, it is already a radiate embryo, and the animal, in all the other phases of its life, remains invariably $r a-$ diate.-Comptes Rendus, Jan. 4, 1847.

\title{
Remarks on Opalina Naïdos, an Entozoon found in the Naïadæ.
} By Dr. O. Schmidt.

The very interesting discovery of this entozoon was made in a species of Naïs nearly allied to N. elinguis, which is furnished with a bundle of hooks at each fourth hook. When the Naïd lies upon its side, a spot in which the oral fissure appears as a notch and the ciliary motion in the œsophageal bulb may be very distinctly perceived. I was looking for the fleshy ridges, which in Stylaria I correctly considered to be regarded as forming the tongue, and was delighted on perceiving that a somewhat elongated body situated in the œsophageal bulb, and which was pointed anteriorly, frequently moved nearly as far as the oral fissure, and then, as it appeared to me, was again retracted. I had not expected to find so moveable a 
tongue, especially as I had not hitherto seen any trace of it in Naïs, and was thus anxiously watching its motions when suddenly the body turned round with ease, and I recognised in it a distinct animal.

It is a polygastric Infusorium, belonging to that genus of which one species occurs so abundantly in the rectum of the frog, but it is somewhat longer, corresponding to the form of the animal within which it lives. It is whitish, entirely covered with cilia, which are only visible when highly magnified, and are regularly arranged in rows. Within it I detected a row of perfectly transparent vesicles. The form of the body is susceptible of various alterations.

After I had watched the motions of Opalina Naïdos, the name given to this animal, for about a quarter of an hour in the œsophageal bulb, during which time it was moving forwards and backwards, it turned round near the mouth and receded further into the intestinal canal, in which, at first, I could not detect it. However, it returned several times with the activity peculiar to these animals, and which was not in the least impeded by the ciliated epithelium of the intestinal canal.

My sight however had become more acute during the period of observation, and hence I soon detected it in the middle of the Naïd and among several other individuals, all of which were in active motion. The circumstance that Stylaria and Naïs, according to Müller's and my own observations, take up only finely-divided nutritive matter, is so completely opposed to the supposition which I myself made of their being Infusoria which had been swallowed, that it cannot be entertained.-Müller's Archiv, 1846, part iv.

\section{On the Formation of Cylindrical Masses of Snow in Orkney.}

\section{To Richard Taylor, Esq.}

Sandwick Manse by Stromness, Feb. 11, 1847.

MY DEAR SIR,-A curious phænomenon in this parish has astonished and perplexed all, and filled the superstitious with no small degree of consternation. Since the 6th inst. we have had hail- or snow-showers, on the 9th snow-drift, and yesterday a slight thaw with frost again in the evening.

During the night a heavy fall of snow took place which covered the plain to the depth of several inches. Upon this pure carpet there rest thousands of large masses of snow which contrast strangely with its smooth surface. A solitary mass may be seen in a field, but in general they occur in patches from one acre to a hundred in extent, while the clusters may be half a mile asunder, and not one mass to be seen in the interval. These fields appear at a distance as if cartloads of manure had been scattered over them and covered with snow but on examination the masses are all found to be cylindrical, like hollow fluted rollers or ladies' swan-down muffs, of which the smaller ones remind me, from their lightness and purity, but most of them 


\section{$2 \mathrm{BHL}$ Biodiversity Heritage Library}

Schmidt, Oscar. 1847. "Remarks on Opalina Naïdos, an Entozoon found in the Naïadæ." The Annals and magazine of natural history; zoology, botany, and geology 19, 284-285. https://doi.org/10.1080/037454809494555.

View This Item Online: https://www.biodiversitylibrary.org/item/19437

DOI: https://doi.org/10.1080/037454809494555

Permalink: https://www.biodiversitylibrary.org/partpdf/18950

\section{Holding Institution}

Natural History Museum Library, London

\section{Sponsored by}

Natural History Museum Library, London

\section{Copyright \& Reuse}

Copyright Status: Public domain. The BHL considers that this work is no longer under copyright protection.

This document was created from content at the Biodiversity Heritage Library, the world's largest open access digital library for biodiversity literature and archives. Visit BHL at https://www.biodiversitylibrary.org. 